\title{
Scriptural Solution to the Implacable Poverty Widespread in the Current Administration in Nigeria: Comparative Analysis
}

\section{Abdulkabir Olaiya Suleiman*}

Skola Research Islāmic Foundation, Head Office, Atari Area, Offa, Kwara State, Nigeria

\begin{abstract}
Poverty has triggered perilous spectrum to the life of people in Nigeria ever than before this current administration and thus, more than 60 percent were living in despicable famine, 20 percent were on the breadline, 10 percent were neither rich nor poor which as a result of this assessment only 10 percent can boast of their three time meals. This paper submits that poverty can simply be termed as deficient or insufficient means of living to survive economic standard because of low income and exorbitant cost of living that above financial capacity. This research discovered that Nigeria Government is on the lookout for possible way out of impecunious hunger that engulfed not only the orphans or Internally Dispersed Person (IDP) but also those who have liberty yet their daily or monthly earning did not sufficient for their living because of high cost of buying and selling of goods and services. Based on the axiomatic fact, the findings apprehends that the realm of poverty has downtrodden the peace and unity in the Nigeria's first stanza. The paper therefore intends to highlight the Nitty-gritty of the divine justification on how to alleviate poverty with Qur'ānic and Biblical conception as therapeutic prophecy. The paper will rely on descriptive and comparative approach to justify the scriptural interference on the poverty alleviation in Nigeria.
\end{abstract}

Keywords: Implacable poverty; Despicable famine; Impecunious Hunger; First stanza; Therapeutic prophecy

\section{Introduction}

Poverty is a financial incapacity or state of lacking basic requirement to live rational life. Basic requirement such as money, food, water and shelter among many others are the scourge of poverty which demoralized the less privilege to be inflicted with the wrath of anomaly. Despite the fact that federal Government is looking towards absolute solution to curtail the widespread of poverty in Nigeria yet all their efforts proved abortive not only because of the economic meltdown but also their policies favour only political gangsters, influential people and minority individual among many others.

Poverty is a persistent problem rampant in Nigeria with impecunious complication despite the series of anti-poverty programs and policies in her history to assuage the economic downturn. Meanwhile, there are many definitions as well as intense debates about the exact number of the poor, where they live and how their numbers and economic condition can change time to time [1].

However, the vigor of poverty in the $21^{\text {st }}$ century has gone beyond control and stood above $80 \%$ especially when the price of good and service inflated with more than 60 percent which lead to the abrupt death of many Nigerian across the country. In essence, the consequence of poverty has a direct effect on not only the life of individual but also on the economic scenario and on the level of their material progress and civil development, causing over billion of people in the world today to live under unacceptable conditions of poverty and around 30,000 people in the die every day because they are too poor to stay alive [2].

Therefore, the study submits that poverty as the major problem facing Nigeria especially the current administration. As a result of this, the infectious wing of poverty has incapacitated financial system of more than 80 percent Nigerian especially the civil servants and the general mass. Therefore, the notion of this paper is to proffer divine resolution to the poverty through the efficiency of the scripture with limitation to the Qur'ānic and Biblical perception.

According to the Qur'anic teaching, poverty is the inability to appropriately withstand social, financial needs or inability to survive the blight of inflation of buying and selling of good and service with money or even being in a death-defying famine. This study accentuates the role and significance of Zakat and Waqf properties as well Sadaqat as a momentous mechanism of alleviating poverty among the underprivileged Nigeria.

The institution of Zakat, Waqf and Sadaqat are among several appliances instituted by Islām to tackle poverty and develop advantageous welfare in the society. The fact remains that Allāh has compartmentalized the rich and the poor yet $\mathrm{He}$ enjoined the rich to pay Zakat as time due or donate to the poor from their property or deliberate almsgiving not only to lessen the burden of the poor but also engender the flow of found and forbid accumulation of money and property. In the effect of this, Bello [3] propounds that Zakat helps to generate a flow of funds and Waqf provides the material infrastructure and create a source of revenue for the use in social welfare enhancement.

In the same vein, Sadaqat on its own is a charitable contribution giving to the poor and needy voluntarily to enhance their sustainability. In the remark of Amuda [4] Zakat, Waqf Sadaqat had the potential to be recognized as a credible and effective institution to gather fund in the interest of less privilege Nigeria.

In the teaching of Christendom, poverty is a complex problem that has to be holistically dealt with. The ministries has the privilege to provide holistic response to poverty in three area as propounded by Adam [5] who was reported to have said, firstly, the church is furnished with a vocation to care for the poor, to alleviate the suffering

${ }^{*}$ Corresponding author: Suleiman AO, Skola Research Islāmic Foundation, Head Office, Atari Area, Offa, Kwara State, Nigeria, E-mail: afakabirskola@gmail.com

Received November 01, 2016; Accepted December 15, 2016; Published December 23, 2016

Citation: Suleiman AO (2016) Scriptural Solution to the Implacable Poverty Widespread in the Current Administration in Nigeria: Comparative Analysis. Intel Prop Rights. 4: 172. doi: 10.4172/2375-4516.1000172

Copyright: (C) 2016 Suleiman AO. This is an open-access article distributed under the terms of the Creative Commons Attribution License, which permits unrestricted use, distribution, and reproduction in any medium, provided the original author and source are credited. 
and to stand for the justice. Secondly, the biblical faith affirms that all are equally valued and have part to play in God irrespective of their soci-economic standing. Thirdly, the church provides a redemption community in which change is normative as mind are renew and lives are transformed and caught up with God's purpose.

Meanwhile, the churches across the country have a glorious role in assuaging poverty in Nigeria. This can be ascertained through their teaching in church and their respond toward the underprivileged member. In spite of the fact that, tithe is necessary as ten percent of the net arrear yet the pastors should know that, any inspiration and teaching that can disregard or undermine the poor should be avoided because their preaching must be a process to alleviate poverty.

However, the current disquiet for economic recession and the scope to alleviate poverty in Nigeria needs to be replaced with appropriate way out for the untenable living of the poor people, devaluation of money against dollar and inappropriate economic. Because, Nigerian poverty situation has been described as an embarrassment and inaptness to her abundant natural resources buoyed by oil wealth discovered since 1953 . It is worthy of notice at this juncture that poverty had led many people to frustration and anger and according to Casimir, et al. [6], poverty is one of the problems that marginalized the poor to join culture and religious group alien to their original faith.

The government policies for poverty reduction in Nigeria may not be feasible without a clear definition of poverty that could be measured with unbounded resolution across country. However, the purpose of this paper is not only to develop religious solutions through scriptural references but also to review some of the strategies based on trials and errors programs for poverty alleviation propound by the federal government whether their objectives surpass the religious ethical courage towards poverty or not.

\section{Statement of the Problem}

Nigeria is a large country both in terms of size and population with mammoth natural resources and valuable farm produce that grows on their soil yet the number of poor ever-increasing geometrically. On a daily basis, both newspaper and internet media overflowing with incorrigible reports such as; 'More than 2000 people perished yesterday of extreme poverty, 100 children dead of malaria because they could not afford hospital bill, 20 people died of Lassa fever while guzzling Gari, 18 people lost their lives in unavoidable collision because of bad road, 12 people died of Ebola virus, many Orphan die on scavenging for food, thousands of Internally Disperse person lost their life in starvation etc.

It is pertinent to note that Nigeria was rated among top twenty poorest countries in the whole world because of poverty that predominantly mete out despite the amount of crude oil, natural gas produced in Nigeria. As the decades have gone by, the number of poor increasing day by day [2]. The poor die in hospital where there is no drug, in villages that lack anti-malarial bed nets, in houses that lack safe drinking water [1].

Although both federal and state level have one way or the other adopted decisive approach to tackle the menace of poverty yet all their efforts did not work because few people control the wealth in Nigeria with full of corruption and injustice to have tear down the economic intensification sporadically. Ndyabahika [7] opines that instead of the wealthy people to give the poor, the rich man comfort themselves with the narrow-minded sight that the materially poor are poor because they are lazy, unfortunate or destined to be poor. To this effect the gap between the poor and rich widens every day.
The hardship of poverty in Nigeria had broadened to every corner with catastrophic effect on both men and women, old and young, educated and non-educated, military and paramilitary, government parastatal and civil servant which leads more than 80 percent Nigerian to live under precarious condition. As a matter of fact, there are many Qur'ānic and Biblical teaching that can be of advantages for poverty alleviation if federal government implements it. This research explored the use of scriptural approach to measure the perception and how to completely assuage poverty in Nigeria.

\section{Literature Review}

Historically, poverty is a problem as old as human existence itself which has been a cause of concern in every society. Poverty has no specific definition that why many writers agreed that, it is multifaceted situations which means different thing to different people, societies and countries. In essence, it is difficult for the humanity to understand the conceptual effect of poverty and decisive measure to its reduction [8]. In the light of this, millions of human souls on earth are living with severe appalling poverty and horrendous condition which is quite alarming. In fact everyone is talking about poverty mitigation and some strategies to be charged for its alleviation [9].

The pain of poverty recently came under the limelight and has been a focus of international community. It is one of the widespread and dangerous problems faced by humanity today [10]. The prevalence of poverty in many parts of underdeveloped country despite the exceptional economic growth has spawned interests in the scourge of academic and policy-making circle [11].

Ayoade and Adeola [12] reiterates poverty in its most extreme form as lack of human needs such as adequate and nutritious food, clothing, housing, clean water and health services. He agreed that extreme poverty can cause terrible suffering and death, and even modest levels of poverty can prevent people from realizing many of their desires. Sirageldin [13] asserts that the societal approaches to poverty alleviation varied significantly from indifference to active intervention from reliance on private or collective strategies and between distributions and the prevailing social value.

Poverty is a topical issue in Nigeria and its reality is manifested in worsening incidence and severity over the years, despite the vast human and natural resource, economic and human potentials the country is blessed with. The issue of poverty is multidimensional and encompasses issues such as inadequate income, malnutrition and poor social status especially in the rural area [14]. In the light of this, Bello [3] dichotomizes the reflection of poverty into absolute and relative poverty. He defines absolute poverty otherwise known as extreme poverty as a situation in which people barely survive, where the next meal may literally to be a matter of life or death. He confirmed that relative poverty on the other hand, is a situation where by there is lack of income necessary to satisfy essential non-food such as clothing, energy and shelter, and exists as long as there is inequality in income and wealth distribution.

In the same vein, Sachs [1] extends poverty into three divisions such as extreme (or absolute) poverty, moderate poverty and relative poverty. He submitted that extreme poverty means that households cannot meet basic needs for survival. They are chronically hungry, unable to access health care, lack of amenities of safe drinking water and sanitation. According to him, Moderate poverty can be refers to the conditions of life in which basic needs are met averagely and Moderate poverty is generally construed as a household income level 
below a given proportion of average national income. The relative poor in high income countries, lack access to cultural goods, entertainment, recreation education and other prerequisite for upward social mobility.

Alamu, et al. [15] submits report on the World Food Summit in Rome in 1999 with approximation that 790 million people in the developing world do not have enough food to eat. Nigeria is one of the developing countries affected by hunger, deprivation and abject poverty by its citizenry in spite of its enormous natural and human resources. Omoregbe and Edeogbon [16] in his study on diversification of livelihood among rural households noted that $90 \%$ of poor households relied on farming as a source of income.

Recently, Dangote [17] points out that the current economic downturn in Nigeria have further worsened the situation, as the government continued to record dwindling revenues, thus making it increasingly difficult for it to fulfill some of its obligations to the people. He stressed further; "It is estimated that more than 100 million out of a population of 187 million Nigerians live below the poverty line. Couple with this, the activities of insurgent in the North-East have also affected the level of poverty in that country". Is it estimated that there are more than 2.4 million Internally Displaced Person are living in the region [17].

However, Ondari [18] opines that poverty and human deprivation have been recognized as the most central challenges to the development of human society ever since the down of history. According to him, poverty is considered a major constraint to any form of development of human being. Meanwhile, the ways of eradicating it are intensely studied and research in several academic disciplines like economics, history, politics, theology, sociology and even law.

Meanwhile, since Nigeria got independence in 1960, the country has been struggling to alleviate poverty in her economy. Abdussalam et al. [19] restates that many efforts have been taken by the government through various policies and programmes to alleviate pain of poverty in Nigeria. He revealed that in these programmes poor people are given relatively small capital to establish themselves on small scale business and the target-population of the programmes are rural poor, illiterates women and unemployed graduates in urban centre.

It is essential to evaluate the impact of these so as to enhance the efforts of the government and available resources towards improving the quality of life of the people. As a result of this, Ayoade et al. [12] confirms that National Special programme for the Food Security (NSPFS) was implemented to ensure food security and alleviate poverty among women and men in Nigeria. He asserts that, the programme is meant to assist the farmer increase their output and income in order to strengthen extension delivery with simple farm technologies and to utilize the land, water and other resources for food production through the loan disbursed for the project.

Adebayo [20] notes that the roles which the latter category plays in poverty alleviation programs in the world over. According to his opinion, non-governmental organizations have changed the historic failures of the government to look in to the root cause of poverty. To this effect, Adesanoye and Okinmadewa [21] accepts that, the high incidence of poverty in Nigeria is persistence despite the myriads of interventions by Government and non Government organization to reduce it through poverty alleviation programmes and projects has brought the issue of vulnerability to the attention of policy makers. Meanwhile, poverty alleviation is but significant to Nigeria since poverty is one of the social problems that have bedeviling the country over the years. In addition, poverty has been predominant in Nigeria as Ayoade et al. [12] simply put it, despite the vast natural resources and human potentiality the country is blessed with. Ammani et al. [22] declares that Islam is a complete way of life that leaves no stone unturned. According to him Zakat as an obligatory command which demands every muslims male or female possessing an amount of wealth equal or exceeding the described amount called Nisab to pay at the passage of year of ownership of such wealth a prescribed potion to specifically eight categories of people enlisted in the Qur'ān, thus “Alms are for the poor and the needy, and those employed to administer the (funds); for those whose hearts have been (recently) reconciled (to truth); for those in bondage and in debt, in the cause of Allāh, and for the wayfarer; (thus is it) ordained by Allah, and Allah is full of knowledge and wisdom" (Yusuf Ali, Quran 9:60).

The verse cited above did not only explicate the significance of Zakat as a channel to permanently assuage poverty but also clearly elucidate on the categories of people to whom the disbursement of Zakat will be appropriately considered.

The corollary of the above assertion can be found in biblical nomenclature and literature of the missionary. It is essential to note that, poverty and attempt to alleviate is an issue that concerns the ministry. In the word of Ayiemba, et al. [23] the Christian church, in spite of its central mandate being a spiritual evangelism has continued to participate in the fight against poverty to accomplish Christ's mission in wholeheartedly serve and minister to both rich and poor in the world. In the light of this, Theuri [24] argues that the people who suffer in life, poverty afflicted them psychologically, emotionally, spiritually, physically and at the same time affect their family, community and social relation.

According to the global Dictionary of Theology [24], poverty is the condition of people which can be described with the abstract noun "the poor". That is why Dyrness and Karkkainen [25] observed that many people tend to view the poor as a group that is helpless. The poor people take it upon themselves to use names such as homeless, destitute, indigenous, working poor to mention but few. Meanwhile the Bible has a vocabulary for the describing the poor and their situation which according to Nyagwoka [26] indicates the attention paid by the Biblical authors to the question of poverty. However, the meaning of particular words does not always remain the same, it shifts as the situation develops and changes. Ojo [27] states that, poverty remains one of the problems of life despite the economic programmes by persons and nations to deal with it. According to him the statement by Jesus that "the poor you will always have with you" (Matt 26:11, NIV) is historically and globally relevant. On a contrary, Adejei revealed that poverty is inimical to human development and it is a threat to the well being and survival of any individual because it has capacity to dehumanize a person by depriving the individual the basic needs such as food and shelter which are essential for human sustenance. Ahmad et al. [28] substantiates that the strategies for poverty alleviation from Islamic legal perspective, have been continues efforts to make Zakat and Waqf instrumental in Nigeria. Amuda [4] conclude that Muslims are wallowing in the abject poverty due to their insufficient income. However, the principal object of this research was to find out the extend of poverty in Nigeria as well as to examine the Islamic and Biblical perception to respond to the poverty congruence to the scriptures.

\section{Quranic Conception on Poverty Alleviation}

Islām is a religion of serenity and harmonious constancy that teaches ethical value and moral standard with the guide of revelation from Allāh to the prophet Muhammad (PBUH) as a solution for 
the entire humanity. The religion of Islām proffers apt solution for the whole humanity through code of conduct based on divine fundamentalism. Suffice it to say, Islām is a religion which encourage betterment of livelihood such as alleviation of poverty, establishment of sound education with standard curriculum, provision of good health care, conception of Peacebuilding and conflict revolution to mention a few. In the light of this, the teachings of Islām accentuate the reason why Muslims must be kindhearted and compassionate with other counterpart. The Qur'ann enjoins Muslims to give either required charity known as Zakat, or endowed some of your property to the needy or deliberate freebie simply referred to as Sadaqat with intention of helping the less privilege to relieve their daily need, Qur'ān read thus,

"And render to the kindred their due rights, as (also) to those in want, and to the wayfarer: But squander not (your wealth) in the manner of a spendthrift. Verily spendthrifts are brothers of the Evil Ones; and the Evil One is to his Lord (himself) ungrateful. And even if thou hast to turn away from them in pursuit of the Mercy from thy Lord which thou dost expect, yet speak to them a word of easy kindness. (Yusuf Ali, Quran 17:26-28).

However, Qur'ān makes it clear that the Islāmic approach towards poverty alleviation is sufficient of providing reasonable solutions to the present-day economic, social, and political problems that overwhelmed Nigeria. Specifically, the problem of poverty could be resolved by putting Islāmic principles in the fundamental operation and the implementation of poverty alleviation programmes. The fundamental teaching of Islām teaches Muslims to pay Zakat and to make donation in order to transform the life of the poor, needy and unfortunate people. Islām also encourages helping and supporting each other in the case of needs. The evidence of this can be found in Qur'ān 2:177, Qur'ān 3:93, Qur'ān 2:262-263, Qur'ān 47:38, Qur'ān 3:180 among many others. Meanwhile, in reference to the significance of assuaging poverty from the deprived and underprivileged people Qur'ān 2:273 read thus, [Charity is] for the poor who have been restricted for the cause of Allah, unable to move about in the land. An ignorant [person] would think them self-sufficient because of their restraint, but you will know them by their [characteristic] sign. They do not ask people persistently [or at all]. And whatever you spend of good - indeed, Allah is Knowing of it" (Muhammad Taqi-ud-deen and Mausin Khan Qur'ān 2:273).

The establishment of Zakat is one of the outstanding solutions laid down by Qur'ānic principles towards eradication of poverty. Islamic scholars agreed that the concept Zakat is not bring about expedient flown of cash within the Ummah but also unnecessary forbid hoarding of money. It is pertinent to not at this junction that, the institution of Zakat as superfluous instrument is enough to tackle the scourge of famine in Nigeria if fully implemented. In addition, Zakat creates favorable conditions for the poor and the needy as Possumah and Ismail [29] confirmed that the implementation of Zakat provides appropriate system for the circulation of money from the affluent people to the vagrant people.

In the same vein, Waqf is an Arabic statement which simply means valuable assets, precious property and material goods that are donated, endowed, bequeathed, or purchased for the premise of endless charity (Sadaqah Jariya) which confer on the inopportune people for enhancement of Muslim society.

Theoretically, Waqf is religious donations voluntarily give out of one's wealth to enhance other people's life in line with Shari'ah. It is indispensable to note that the position of Waqf in Islam as an integral part of poverty regulation the reenactment of social-economic life of
Muslim. The prominent forms of Waqf include valuable property such as land, buildings, cattle, funds among many others. To this effect, Qur'ān 2:270 encapsulates thus,

"And whatever you spend of expenditures or make of vows indeed, Allāh knows of it. And for the wrongdoers there are no helpers. (Yusuf Ali, Qur'ān 2:270),

Waqf is recognized by the Islāmic law as religious, pious or charitable donation. Therefore, the realization of Waqf as a means of improving the society with the charitable endowment as time due not increase the vibrant infrastructure but also enable the poor to have property such as building, land and other valuable material goods such as Mosques, educational institutions, libraries, hospital and other contemporaneous infrastructures. Meanwhile, the benefits of Waqf are not restricted to the Muslim community alone but go beyond religious, cultural, racial and sectarian boundaries.

"O ye who believe! Shall I lead you to a bargain that will save you from a grievous Penalty? That ye believe in Allāh and His Messenger, and that ye strive (your utmost) in the Cause of Allāh, with your property and your persons: That will be best for you, if ye but knew!" (Yusuf Ali, Qur'ān 61:10-11).

In spite of having divine tool of poverty alleviation like Zakah and Waqfu, many Muslims still pay no or little attention to the Islāmic instructions on the management and distribution of their wealth. This is not only because some Muslims lack Islāmic moral as well as knowledge about the significance of Zakah and Waqfu but also absence of effective Zakah management institutions both in government and private level in Muslim societies [30].

\section{Biblical Conception on Poverty Alleviation}

Comparatively, the teachings of the Bible also proffer way out to poverty as the burning issues of our time. This is affirmed with the dynamic philosophy of Jesus Christ that taught the disciple the benefit of becoming compassionate to the poor people. Jesus lived a model life worthy of emulation especially his teaching on how to fellowship with the poor will according to him enable your heart to be connected with God. Jesus was reported to have said, "if anyone with earthly possession sees his brother in need, but withholds his compassion from his, how can the love of God abide in him?" (KJV, 1 John 3:17). In the light of this, the book of Luke also elevates the position of the poor as thus, "Blessed are you who are poor, for your is the kingdom of God" (KJV, Luke 6:20).

The book of proverb illuminate the severe subsequence in oppresses the less privilege, such as; "whoever oppresses the poor shows contempt for their maker, but whoever is kind to the needy honors God" (KJV, Prover 14:32).

The popular word in the bible for "the poor" is 'anawim'. This Hebrew word demonstrates a situation of social and economical inadequacy. However, the biblical terminology on the poor is much more extensive than texts dealing with the 'anawim. Other important terms occur as 'ebyon meaning one who is poor and must beg; dal meaning one who is weak in both social and physical sense [31]. That why the Bible unequivocally said; You shall not oppress a hired servant who is poor and needy, whether he is one of your countrymen or one of your aliens who is in your land in your town (KJV, Deuteronomy, 24:14). The missionary is of opinion that poverty can simply be termed as common occurrence and state of lacking requirement and daily needs which culminates unbearable anguish to the poor people. Despite 
the fact that Jesus portraits the requisite upon the rich to assist the poor yet many Christian neglect the act of being kindhearted to the lesser people as a yardstick of faith in the Christendom. The Bible recorded to have said in Proverb 14:30, thus "A tranquil heart is life to the body, but passion is rottenness to the bones, he who oppresses the poor taunts his maker, but he who is gracious to the needy honors him, the wicked is thrust down by his wrongdoing, But the righteous has a refuge when he dies" (New American Standard Version, Proverb 30-32) Poverty is a condition of having insufficient resources or income and can also be defined as a state of one who lacks a certain amount of material possessions or money [32-35]. To this effect, the bible emphatically stated the significance of helping the people as stated in the book of Exodus 23:10-11, the book of Deuteronomy 14:29, 26:12 and 24:29-32, the book of Leviticus 19:9-10 and 23:22 as well as Leviticus 25:1-7to mention a few. Painstakingly, the Bible was recorded to have clearly stated thus, "Who is like the Lord our God, the one who sits enthroned on high, who stoops down to look on the heaven and the earth? He raises the poor from the dust and lifts the needy from the ash heap, he seats them with princes, with princes of their people" (KJV, Psalm 113)

In essence, Poverty continues to spread wing in Nigeria as a result of individual's failure to understand the significance of charity and to be compassionate. That is why Ayiemba et al. [23] reaffirmed that poverty occur in a situation whereby the affluence people tightfisted their hand to give the poor which incapacitate the poor people meet daily need such as provision of food for the immediate family, inconvenient housing, shabby cloth, lack of medical care and chance for education [36,37].

\section{Conclusion}

Poverty has triggered importunate problem to the life of people in Nigeria ever than before this current administration and thus, more than 80 percent of people were living in despicable famine in order to survive with economic meltdown based on their level of income and access to basic human necessities, such as food, water, and shelter.

Meanwhile, poverty is the yardstick of all problems stumbling upon Nigerian because the gap between the wealthy and the deprived people is too far than the probability. Without iota of doubt, poverty is a classic and importunate problem in existence. Many ways have been introduced to alleviate poverty in Nigeria such as Government and non-Government programme, National and international institution of poverty alleviation, Religious Organization among many others.

To this effect, poverty is an obnoxious situation when people are deprived from access to many things but most common of these are adequate levels of health care, food, shelter, clothing, education, literacy, knowledge, water, sanitation, economic opportunity and economic resources and community participation. This research finds that Nigeria Government is looking for the possible way out of impecunious hunger and starvation that combats not only deprived widow, unfortunate orphans or Internally Dispersed Person (IDP) but also those who have liberty yet their daily or monthly earning did not sufficient for their living because of high cost of buying and selling of goods and services.

The objectives of this paper are to create perceptive concept of poverty through the Quranic and Biblical perception by scrutinizing the multifaceted dimensions of apt solution from divine source. In addition, this study examines the magnitude of poverty and the fault of Government policies in transforming Nigeria into substantial famine.

\section{Suggestions and Recommendations}

1. The teaching of both Qur'ān and Bible painstaking point to the principle of compassionate, so therefore, the exponent of the due religion should concede to the message by assisting the less privilege in order to assuage poverty.

2. Islāmic and Christian scholars should try to educate the society on the significance of charities to the community and society especially for the less privileged to enhance their living.

3. Due to the shortage of food, poverty continue to afflict the life of Nigerian, this study therefore recommends that Government should invest more in farming especially in rural areas to increase the purchasing power of households and also to provide immediate necessity to human sustenance.

4. Development policy-makers and practitioners could also use Islāmic sacred texts and Biblical conception in their awareness campaign (directed to the general public) to alleviate poverty through the following guiding principles from divine sacred texts.

5. The rich become rich because (Allāh) God wants them to be rich and the poor has become choice against the destiny, therefore, the rich should fear (Allāh) God who create them to be among the rich and he will ask them how made use of the gift.

\section{References}

1. Sachs JD (2005) The End of Poverty Economic Possibilities for Our Time, Published by the Penguin Group Penguin Group (USA) Inc. 375 Hudson Street New York, New York.

2. Dogarawa AB (2006) Combating Poverty through Self-Reliance: The Islamic Approach, Journal of Business Administration, Ahmadu Bello University, Zaria 1: 1.

3. Bello DA (2009) Poverty Alleviation through Zakah and Waqf Institutions: A Case for the Muslim Ummah in Ghana. Being a Paper Presented at the First National Muslim Summit organized by Al-Furqan Foundation, Tamale, Ghana Held at Radach Memorial Centre, Lamashegu, Tamale, Ghana13: 38.

4. Amuda YJ (2013) Empowerment of Nigerian Muslim Households through Waqf, Zakat, Sadaqat and Public Funding. International Journal of Trade, Economics \& Finance 4: 6

5. David A (2012) The role of the church in combating poverty and inequality in South Africa: a case study from Cape Town, Poverty \& Inequality Conference, Paper presented at towards Carnegie 111, conference held at the University of Cape Town.

6. Ani C, Nwaoga CT, Ogbozor C (2014) Religion, Violence, Poverty and Underdevelopment in West Africa: Issues and Challenges of Boko Haram Phenomenon in Nigeria, Open Journal of Philosophy.

7. Ndyabahika J (2007) Biblical Economy,Wealth And Poverty: A Challenge To The Great Lakes Region Of East Africa , McMaster Journal of Theology and Ministry, NDYABAHIKA Biblical Economy, Wealth and Poverty, Africa University-Zimbabwe.

8. Akindola RB (2010) Causes of Poverty: Voices of the Rural Poor from Oyo State, Nigeria. Journal of Social Development in Africa, 25: 1.

9. Hossain MZ (2012) Zakat in Islam: A Powerful Poverty Alleviating Instrument For Islamic Countries, International Journal of Economic Development Research and Investment 3: 1.

10. Damilola WO, Nassir AB, Baba HS (2015) The Role of Zakat as a Poverty Alleviation Strategy And a tool for sustainable development: insights from The perspectives of the holy prophet (pbuh), Arabian Journal of Business and Management Review (OMAN Chapter) 5: 8-17.

11. Adepoju RI, Oyesanya OS (2014) A Critical Analysis of Poverty Alleviation Strategies of Al-Hayat Relief Foundation in Nigeria. Journal of Islamic Finance 3: 49-59. 
Citation: Suleiman AO (2016) Scriptural Solution to the Implacable Poverty Widespread in the Current Administration in Nigeria: Comparative Analysis. Intel Prop Rights. 4: 172. doi: 10.4172/2375-4516.1000172

12. Ayoade AR, Adeola RG (2012) Effects of Poverty on Rural Household Welfare in Oyo State, Nigeria. Global Journal of Science Frontier Research Agriculture \& Biology 4: 45 .

13. Ismail S (2000) Elimination of Poverty: Challenges and Islamic Strategies, Islamic economic studies. Islamic Economic Studies 8: 1.

14. Olowe K (2002) Gender Dimensions on Poverty Alleviation in Nigeria. Workshop on Gender and Sustainable Development. August 26-30 NCEMA Ibadan.

15. Alamu SO, Abiodun JA, Miller JW (2005) Food security and poverty alleviation under the National Special Programme for Food Security: a preliminary socioeconomic assessment of Yamama Lake, Kebbi state, Nigeria. In: 19th Annual Conference of the Fisheries Society of Nigeria (FISON) Ilorin, Nigeria, 149-162.

16. Omoregbe FE, Edeogbon CO (2006) Diversification of Livelihood among Rural Households in Owan -West Local Government Area, Edo State. Nigeria. Global Journal of Social Science 5: 1 .

17. Dangote (2016) 100 million Nigerians living in poverty, Published by Nigeria Punch.

18. Ondari, William O (2001) Poverty And Wealth: A Christian Perspective, Institute for Christian Teaching, Old Columbia Pike, Silver Spring, USA. Prepared for the 28th International Faith and Learning Seminar held at Babcock University, Ilishan-Remo, Ogun State, Nigeria.

19. Abdussalam O, Johari F, Haji Alias M (2014) Managing Immediate Action for Women and Poverty Reduction in Nigeria: an Explanation from the Generic Theory, Leena and Luna International, Oyama, Asian Journal Of Management Sciences \& Education, Japan. 3: 1.

20. Adebayo AA (1997) The roles of NGOs in poverty alleviation in Nigeria: A case study of Nigeria Economic Society 4: 1-2.

21. Adesanoye AO, Okunmadewa FY (2011) Households Vulnerability to Poverty in Ibadan Metropolis, Oyo State, Nigeria. Pakistan Journal of Social Sciences 4: 120.

22. Ammani SA, Abba SA, Dandago KI (2014) Zakah on Employment Income in Muslims Majority States of Nigeria: Any Cause for Alarm? International Conference on Accounting Studies 18-19 August 2014, Kuala, Lumpur, Malaysia 306.

23. Ayiemba JO, Theuri MM, Mungai PC (2015) The mandate of the Christian church in poverty alleviation: the case of the Anglican church of Kenya (ACK) in Maseno and Winam divisions of Kisumu district, Kenya, International Research Journal of Arts and social Science 4: 43-54.

24. Theuri MM (1994) The Meaning, Causes and Solutions of Poverty in The Papal Encyclicals (1878-1990) and The Documents of Vatican II; An African Theological Critique. Michigan: A Bella and Howell.
25. Dyrness WA, Karkkainen VM (2008) Global dictionary of theology. Nottingham: Inter-Varsity press.

26. Joseph BN (2011) A Strategy for Poverty Reduction Among Seventh-day Adventist Members in Kenya Project Documents 94.

27. OJO J (2007) A Christian Theological Response to Poverty. Betfa Journal Ogbomosho Circle 56-65.

28. Ahmad M, Rashid SK, Ibrahim U, Umar AO (2015) The Legal and Regulatory Framework for Zakah and Waqf Administration in kuwait: lessons for Nigerian Zakah and Waqf Institutions, International Journal of Business, Economics and Law 7: 9.

29. Possumah BT, Ismail AG (2011) The Quran and Poverty Alleviation: A Theoretical Model for Zakat-Based Islamic Microfinance Institutions Working Paper in Islamic Economics and Finance No. 1101, Research Center for Islamic Economics and Finance Universiti Kebangsaan Malaysia 2.

30. Hoque N, Khan MA, Deen MK (2015) Poverty alleviation by Zakah in a transitional economy: a small business entrepreneurial framework, Journal of Global Entrepreneurship Research 5: 7-8.

31. Guinan MD (1981) Gospel poverty witness to the risen Christ: A study in biblical spirituality. New York: Paulist Press 15-16.

32. Encarta (2009) Poverty history of poverty causes of poverty and the effects of poverty. "Indicators of Poverty \& Hunger".

33. Godfred AN (2012) Poverty In Ghana: Theological Reflection On The Response Of Some Churches In Kumasi Metropolitan Area, Thesis Submitted to the School of GraduateStudies, Kwame Nkrumah University of Science and Technology - Kumasi, in Partial Fulfillment of the Requirement for the degree of Master of Philosophy (religious studies) Faculty of Social Sciences College of Arts and Social Sciences, Department of Religious Studies.

34. Abdalla AD (2010) Religion's role in Development, Ecology and Climate change: An Islamic perspective, Presentation at the Conference on the role of Religion in Development-focus on Ecology and Climate Change, Finnish Evangelical Lutheran Mission in Helsinki.

35. Boerma C (1979) The rich, the poor and the Bible (B. John, Trans) Philadelphia Westminster Press.

36. William O (2001) Poverty And Wealth: A Christian Perspective,being a pape presented at 28th International Faith and Learning Seminar held at Babcock University, Ilishan-Remo, Ogun State, Nigeria June 17 - 29, 2001, 477-00 Institute for Christian Teaching 12501 Old Columbia Pike Silver Spring, MD 20904 USA.

37. Scheffler E (2013) Poverty eradication and the Bible in context: a serious challenge. In: Scheffler, Heerden V (eds.) Studia Historiae Ecclesiastica 39: 129-153. 